\section{A dinucleotide repeat polymorphism at the D9S109 locus}

R.A.Furlong, J.E.W.Lyall, D.R.Goudie, M.A.Leversha, N.A.Affara and M.A.Ferguson-Smith

Department of Pathology, University of Cambridge, Tennis Court Road, Cambridge CB2 1QP, UK

Source/Description: Clones containing $[\mathrm{CA}]_{\mathrm{n}}$ microsatellites were selected with end-labelled $[\mathrm{TG}]_{15}$ from a flow-sorted chromosome 9 library (derived from a human/hamster hybrid cell line) in Charon 21A. Southern blots of clones containing microsatellites were probed with either human or hamster DNA. Clone $9 \mathrm{CMP} 1$ containing a $[\mathrm{CA}]_{\mathrm{n}}$ microsatellite of human origin was sequenced enabling the design of PCR primers (Yuille et al., 1991). Microsatellite sequence showed the repeat to be $[\mathrm{CA}]_{11}$.

Primer Sequences:

5' GCA CAG GCT GCA ATA TAG AC 3' (CA strand) 5' TTT ACT GTA TAA AAA CTG AAG CTA ATA 3' (GT strand)

Polymorphism: Heterozygosity was estimated at $70 \%$ by analysis of 196 chromosomes from unrelated individuals.

$\begin{array}{lll}\text { Allele } & \text { bp } & \text { Frequency } \\ \text { A1 } & 229 & 0.038 \\ \text { A2 } & 227 & 0.258 \\ \text { A3 } & 225 & 0.279 \\ \text { A4 } & 223 & 0.100 \\ \text { A5 } & 221 & 0.167 \\ \text { A6 } & 219 & 0.158\end{array}$

Chromosomal Localization: 9CMP1 was assigned to 9q22.1-9q32 by PCR across a series of flow-sorted chromosome 9 translocations (Cotter et al., 1989) and to 9q31 by in situ hybridization. 2 point linkage analysis of 9CMP1 with LAMP 92 (Pandolfo et al., 1988) produced a recombination fraction of 0.03 with a maximum LOD score of 10.95 ; and with 9CMP2 (Lyall et al., 1991), a recombination fraction of 0.01 with a maximum LOD score of 8.39.

Mendelian Inheritance: Co-dominant segregation was observed in $19 \mathrm{CEPH}$ families of 2 and 3 generations.

PCR Conditions: 50-100 ng genomic DNA were amplified in a $10 \mu \mathrm{l}$ reaction containing: $125 \mu \mathrm{M}$ dATP, dGTP and dTTP; $25 \mu \mathrm{M}$ cCTP, $1 \mu \mathrm{Ci} \alpha^{32} \mathrm{P}$-[dCTP], $25 \mathrm{mM}$ TAPS pH 9.3, 50 $\mathrm{mM} \mathrm{KCl}, 1 \mathrm{mM}$ DTT, $2 \mathrm{mM} \mathrm{MgCl}{ }_{2}, 0.05 \% \mathrm{~W} 1$ detergent, 50 ng of each primer and 0.75 units Taq polymerase (NBS). Amplification conditions were as follows: $94^{\circ} \mathrm{C}$ for $4.5 \mathrm{~min} ; 30$ cycles of $94^{\circ} \mathrm{C}$ for $0.5 \mathrm{~min}, 55^{\circ} \mathrm{C}$ for $0.5 \mathrm{~min}, 72^{\circ} \mathrm{C}$ for 0.5 min; and a final extension at $72^{\circ} \mathrm{C}$ for $10 \mathrm{~min}$.

Acknowledgements: This work was supported by the MRC Human Genome Mapping Project, and the ICRF.

References: 1) Yuille,M.A.R. et al. (1991) Nucleic Acids Res. 19, 1950; 2) Cotter,F. et al. (1989) Genomics 5, 470-474. 3) Pandolfo,M. et al. (1988) Nucleic Acids Res. 16 7213. 4) Lyall,J.E.W. et al. (1992) Nucleic Acids Res. 20, 925.

\section{A dinucleotide repeat polymorphism at the D9S127 locus}

J.E.W.Lyall, R.A.Furlong, M.A.R.Yuille, D.R.Goudie, M.A.Leversha, N.A.Affara and M.A.Ferguson-Smith Department of Pathology, University of Cambridge, Tennis Court Road, Cambridge CB2 1QP, UK

Source/Description: Clones containing $[\mathrm{CA}]_{\mathrm{n}}$ microsatellites were selected with end-labelled $[\mathrm{TG}]_{15}$ from a flow-sorted chromosome 9 library (derived from a human/hamster hybrid cell line) in Charon 21A. Southern blots of clones containing microsatellites were probed with either total human or hamster DNA. Clone 9CMP2 was shown to contain a $[\mathrm{CA}]_{\mathrm{n}}$ microsatellite of human origin by this process. Direct sequencing out of this $[\mathrm{CA}]_{\mathrm{n}}$ repeat enabled PCR primers to be designed (Yuille et al., 1991). By sequencing with one of the PCR primers, the microsatellite was shown to contain $16 \mathrm{CA}$ repeats, in this clone.

\section{Primer Sequences:}

5' CCC TCA AAA TTG CTG TCT AT 3' (CA strand)

5' AGA TTG ATT GAT ACA AGG ATT TG 3' (GT strand)

Polymorphism: Heterozygosity was estimated at $72 \%$ by analysis of 210 chromosomes from unrelated individuals.

$\begin{array}{lll}\text { Allele } & \text { bp } & \text { Frequency } \\ \text { A1 } & 159 & 0.062 \\ \text { A2 } & 157 & 0.447 \\ \text { A3 } & 155 & 0.034 \\ \text { A4 } & 153 & 0.284 \\ \text { A5 } & 151 & 0.067 \\ \text { A6 } & 149 & 0.106\end{array}$

Chromosomal Localization: 9CMP2 was assigned to $9 \mathrm{q} 22.1-9 \mathrm{q} 32$ by PCR across a series of flow-sorted chromosome 9 translocations and to $9 q 31$ by in situ hybridization. Linkage analysis in CEPH families indicated that 9CMP2 and the LAMP 92 locus (Pandolfo et al. 1988) were linked with a peak LOD score of 8.27 at a recombination frequency of 0.04 .

Mendelian Inheritance: Co-dominant segregation was observed in 31 families of 2, 3, and 4 generations.

PCR Conditions: 50-100 ng genomic DNA were amplified in a $10 \mu$ l reaction containing: $125 \mu \mathrm{M}$ dATP, dGTP, dTTP, 25 $\mu \mathrm{M}$ dCTP, $1 \mu \mathrm{Ci}{ }^{32} \mathrm{P} \alpha$-dCTP, $25 \mathrm{mM}$ TAPS pH 9.3, $50 \mathrm{mM}$ $\mathrm{KCl}, 1 \mathrm{mM}$ DTT, $2 \mathrm{mM} \mathrm{MgCl} 2,0.05 \% \mathrm{~W} 1$ detergent, $50 \mathrm{ng}$ of each primer and 0.75 units Taq polymerase (NBS). Amplification conditions were as follows: $94^{\circ} \mathrm{C}$ for $4.5 \mathrm{~min}, 30$ cycles of $94^{\circ} \mathrm{C}$ for $0.5 \mathrm{~min}, 55^{\circ} \mathrm{C}$ for $0.5 \mathrm{~min}, 72^{\circ} \mathrm{C}$ for 0.5 min and a final extension at $72^{\circ} \mathrm{C}$ for $10 \mathrm{~min}$.

Acknowledgements: We thank Dr Joe W.Gray (formerly of the Lawrence Livermore National Laboratory, Berkley, CA) for the Chromosome 9 library. This work was supported by the Medical Research Council Human Genome Mapping Project, and the Imperial Cancer Research Fund.

References: 1) Yuille,M.A.R. et al. (1991) Nucleic Acids Res. 19, 1950. 2) Pandolfo,M. et al. (1988) Nucleic Acids Res. 16, 7213. 3) Cotter,F. et al. (1989) Genomics 5, 470-474. 